\title{
The Early Milestones of Team-based Learning: The Key is Sustained Practice
}

\section{Ahmad AbdulAzeem Abdullah Omer}

Department of Surgery, College of Medicine, Prince Sattam Bin Abdu Aziz University, Al-Kharj, KSA

ORCID:

Ahmad AbdulAzeem Abdullah Omer: https://orcid.org/0000-0001-8311-8888

Corresponding Author: Ahmad AbdulAzeem Abdullah Omer;

email: ahmedsilik@gmail.com

Received 08 July 2021

Accepted 17 September 2021

Published 30 September 2021

Production and Hosting by Knowledge E

(c) Ahmad AbdulAzeem Abdullah Omer. This article is distributed under the terms of the Creative Commons

Attribution License, which permits unrestricted use and redistribution provided that the original author and source are credited.

Editor-in-Chief:

Prof. Mohammad A. M. Ibnouf

\section{Abstract}

Background: To explore students' perceptions of team-based learning (TBL) initial implementation in a medical school in Saudi Arabia.

Methods: This descriptive study used the validated TBL-Student Assessment Instrument (TBL-SAl) to gauge students' perception of TBL in three subscales: accountability, preference, and satisfaction. Study participants were fourth-year students at the College of Medicine in Prince Sattam Bin Abdul Aziz University, studying a nine-week introductory surgery course in the academic year 2019-2020. Descriptive statistics using the mean scores were used to highlight the results.

Results: Thirty-three students participated in the study. While the mean scores for the three subscales were: accountability 30 (SD 6.6) (neutral score $=24$ ), preference 43.2 (SD 10.8) (neutral score $=48$ ), and satisfaction 25.2 (SD 8.9) (neutral score $=27$ ), the mean of the total questionnaires' scores was 98.4 (SD 21.8) (neutral score $=99$ ). Students expressed a minor level of accountability, poor preference and satisfaction, and an overall low rating of TBL activities.

Conclusion: Low students' engagement with TBL is likely attributed to their unfamiliarity with this approach and the hostility that they may experience when challenged to refrain from passive learning habits and take an active role toward their learning. Lack of the necessary skills and experience to facilitate TBL encounters and the educational climate where didactic teaching is pervasive may be other factors. Exposure to TBL may initially be associated with poor students' perception. Perseverance, strong commitment alongside adequate institutional support are necessarily required to mitigate poor outcomes.

Keywords: active learning, passive learning, team-based learning, Saudi Arabia

\section{Introduction}

Teaching medicine has recently witnessed some significant shifts in its educational paradigms to comply with the overarching roles of today's physicians and the rapidly changing perspectives and standards of local and international healthcare delivery systems [1]. Such pressures implied the move-away from passive learning environments 
to strategies where students take an active role and participate effectively in their learning [2]. Team-based learning (TBL) has recently emerged as an active learning method that transfers the advantages of small group learning into the premises of large traditional classes [3, 4]. Since its first description by Michelsean in the early 1990s in Business schools, it is currently widely implemented in the realm of medical education $[5,6]$. TBL is a form of collaborative learning in which students first perform preparatory readings and then come to the classroom to undertake a series of tests and application exercises individually and in teams [3]. Thus, class time is invested in the application of knowledge in real-world problems rather than the passive transmission of information or mere recall of facts [7]. Within this student-centered approach to learning and where it is nourished with discussion and proper teacher guidance, students' learning is enhanced, and their professional skills can be significantly empowered $[4,8]$.

TBL has been admired for several advantages that it brings to contemporary medical education programs. Some reports have asserted better student engagement, knowledge retention, and academic performance in TBL approaches than traditional lectures [8-11]. Students also valued TBL activities for making difficult material comprehensible and for the immediate feedback integrated into the process [1]. TBL cultivates essential professional skills like problem-solving, critical thinking, leadership and management, and general clinical skills, which are all essential for physicians to perform their future roles $[12,13]$. As students work together to accomplish the goals of their learning, with repeated practice, they develop teamwork skills, particularly communication and shared decision-making $[1,14]$. Such abilities are of paramount importance to medical students as they reflect the nature of their future work with other healthcare givers where decisions regarding patient care are taken collaboratively, and tasks are usually shared $[2,12,15]$. Although TBL employs the same concept of active and small group learning as in flipped classrooms and problem-based learning (PBL), it is unique in some perspectives. TBL grants teachers some control over the learning process by identifying pre-reading assignments and preparing for in-class application exercises. In such a way, TBL is tinged with some teacher directedness while still maintaining its student-centered approach to learning $[9,14]$. TBL is also flexible since sessions can be managed by one tutor in a single classroom where the students are seated around tables, which has essential implications, particularly to resource-limited settings $[5,8,16]$. These characteristics might elucidate supremacy of TBL over other active learning pedagogies and may have contributed to its endearment and growing use currently observable in many medical schools around the world $[4,5,7,17]$. 
The College of Medicine at Prince Sattam Bin Abdul Aziz University (PSAU) in Saudi Arabia administers a hybrid curriculum with integrated system-based teaching in preclinical years (second and third) and discipline-based approach in the clinical years (fourth, fifth, and sixth). The college has recently employed a new curriculum where active small group learning strategies were introduced in conjunction with traditional didactic methods that were pervasive since its establishment. TBL has been introduced in this academic year as part of the new curriculum to lever students' academic performance and popularize its use in the college. The method is first applied in the introductory surgery course (Surgery-1), a nine-week course that introduces the fourth-year students to the basic clinical knowledge and skills for evaluation of common surgical conditions. This study aims to evaluate students' perceptions of TBL as an innovative method in the new curriculum to enhance their learning. Although it may be too early, understanding how students perceive and respond to this active pedagogy may help ease transition from a didactic curriculum into a stage where students take responsibility toward their learning. Such preliminary data would provide evidence of TBL acceptance and applicability in our setting and inform decisions regarding its future implementation. Bedside, such findings could also be of interest to other medical schools intending to undertake such initiative particularly given the increased fortitude of student-centered methodologies in modern medical education.

\section{Materials and Methods}

\subsection{Study design}

This descriptive cross-sectional study aimed to assess students' perceptions of TBL in a medical school where it was implemented for the first time. Eight sessions in the course in which this study took place were taught by a TBL approach while the rest of the teaching material was delivered by a combination of methods including simulation, bedside teaching, and didactic lectures [5].

\subsection{Subjects and materials}

The study population consisted of 42 fourth-year students, who were just starting their clinical rotations, at the College of Medicine in PSAU, in Al-Kharj, Saudi Arabia. The study participants were enrolled in the basic clinical skills course in surgery (Surgery-1) in the academic year 2019-2020. Students were recruited voluntarily to participate in the 
study in February 2020, three months after the conclusion of the surgical rotation. Data were collected from participants using the TBL-SAI, a validated 33-item questionnaire with documented high reliability and content validity [18]. The instrument assesses students' perceptions of TBL in three subscales; accountability to team learning, satisfaction, and preference to TBL or lectures (see the Appendix). Items of the questionnaire were rated by a 5-point Likert scale where strongly Agree $=5$, Agree $=4$, Neutral $=$ 3 , Disagree $=2$, and strongly disagree $=1$. The neutral point of comparison for ach subscale was set at the mid-point plus $10 \%$ of the total score. Arabic translations were added besides the original TBL-SAl questions to address the language concerns which may be raised by the students, and to increase the credibility of the results.

\subsection{Data analysis}

Data were analyzed using the SPPS computer software (IBM Inc. Chicago, Illinois) version 25. Descriptive statistics using the mean score and standard deviation were carried out to highlight the results in each of the three domains of the TBL-SAI. Besides, the average of the total score of all questionnaires was used as a measure of overall students' perception of TBL. Internal consistency and reliability of students' responses to the TBL-ASI items were assessed using the alpha Cronbach statistics.

\subsection{The TBL procedure}

We adopted a TBL strategy that involves all the essential steps, as initially described by Michaelsen [4]. Students were deliberately divided into six groups of seven students based on their Grade Point Average (GPA) to create groups of homogenous academic ability $[3,9]$. In the first session, students were introduced to the objectives and rationale of using TBL and its expected advantages [1, 3]. In lieu of teaching new subject matter, we opted for broad "capstone" topics to assist students to comprehend important curricular areas [3]. In the classroom, each student answered alone 10-item multiplechoice questions as the Individual Readiness Assurance Test (IRAT), and then they attempted the same questions working in their teams as the Group Readiness Assurance Test (GRAT). Students then received immediate feedback about their performance where the facilitator clarified concepts and resolved misunderstandings. Students' valid appeals on wording, structure, or truthfulness of questions were accepted and rewarded once referenced to the study material $[1,4]$. In the application phase $(t A P P)$, students worked in teams to solve clinical problems designed to test the application of knowledge 
acquired during the previous exercises. The " $4 S$ " principle was typically followed; that is, students attempted the same problem, which is significant to which they made specific choices that they reported simultaneously [4]. Teachers were advised to act as facilitators rather than subject experts, for example, to solicit student participation, encourage them to articulate their views and reflect on those of their peers, avoid premature closure of discussion, and prepare students to accept some degree of uncertainty [4]. Finally, the session was concluded with a short wrap-up followed by peer evaluation and evaluation of the teams by the facilitator.

\section{Results}

Thirty-four students (out of 42) participated in the study and completed the questionnaire, giving rise to a response rate of $81 \%$. The Cronbach alpha reliability of the questionnaire's items were $0.82,0.85$, and 0.91 for accountability, preference, and satisfaction subscales, respectively, and that of the overall TBL-SAI was 0.92 indicating high internal consistency in resonance with the high reliability documented for its original version. The range of scores, the mean, and the neutral scores for each subscale and that of the total questionnaires' scores are shown in Table 1. In summary, students showed a minor level of accountability, poor satisfaction, more preference for lectures, and an overall low rating of TBL activities.

TABLE 1: Summary of the students' scores in the three subscales of the TBL-SAI $(N=34)$.

\begin{tabular}{l|l} 
Subscale & $\begin{array}{l}\text { Scores } \\
\text { range }\end{array}$ \\
\hline Accountability (Possible score 8-40) & $16-40$ \\
\hline Preference (Possible score 16-80) & $16-62$ \\
\hline Satisfaction (Possible score 9-45) & $9-37$ \\
\hline Total score (Possible score 33-165) & $41-128$
\end{tabular}

Mean
30.0
43.2
25.2
98.4

\begin{tabular}{l|l}
$\begin{array}{l}\text { Standard } \\
\text { Deviation }\end{array}$ & $\begin{array}{l}\text { Neutral } \\
\text { score }\end{array}$ \\
\pm 6.6 & 24 \\
\pm 10.8 & 48 \\
\pm 8.9 & 27 \\
\pm 21.8 & 99
\end{tabular}

TABLE 2: Detailed students' responses to the TBL-SAI $(N=34)$.

\begin{tabular}{|c|c|c|c|c|c|c|c|}
\hline No. & Item & $\begin{array}{l}\text { Strongly } \\
\text { agree (X5) }\end{array}$ & $\begin{array}{l}\text { Agree } \\
\text { (X4) }\end{array}$ & $\begin{array}{l}\text { Neutral } \\
\text { (X3) }\end{array}$ & $\begin{array}{l}\text { Disagree } \\
\text { (X2) }\end{array}$ & $\begin{array}{l}\text { Strongly } \\
\text { disagree } \\
\text { (X1) }\end{array}$ & $\begin{array}{l}\text { Average } \\
(\div 34)\end{array}$ \\
\hline & Accountability subscale & \multicolumn{6}{|c|}{$\begin{array}{l}\text { Total possible marks }(\text { for each student })=(8 \times 5)=40 \text {. } \\
\text { Neutral point }=\text { midpoint mark }(40 / 2)+10 \% \text { of the total marks } \\
(40 / 10)=20+4=\mathbf{2 4}\end{array}$} \\
\hline 1. & $\begin{array}{l}\text { I spend time studying } \\
\text { before class in order to } \\
\text { be prepared }\end{array}$ & 13 & 12 & 7 & 1 & 1 & 4.0 \\
\hline 2. & $\begin{array}{l}\text { I feel I have to prepare } \\
\text { for this class in order to } \\
\text { do well }\end{array}$ & 13 & 10 & 5 & 2 & 4 & 3.8 \\
\hline
\end{tabular}




\begin{tabular}{|c|c|c|c|c|c|c|c|}
\hline No. & Item & $\begin{array}{l}\text { Strongly } \\
\text { agree (X5) }\end{array}$ & $\begin{array}{l}\text { Agree } \\
(X 4)\end{array}$ & $\begin{array}{l}\text { Neutral } \\
(\mathrm{X} 3)\end{array}$ & $\begin{array}{l}\text { Disagree } \\
\text { (X2) }\end{array}$ & $\begin{array}{l}\text { Strongly } \\
\text { disagree } \\
\text { (X1) }\end{array}$ & $\begin{array}{l}\text { Average } \\
(\div 34)\end{array}$ \\
\hline \multicolumn{2}{|r|}{ Accountability subscale } & \multicolumn{6}{|c|}{$\begin{array}{l}\text { Total possible marks }(\text { for each student })=(8 \times 5)=40 \text {. } \\
\text { Neutral point }=\text { midpoint mark }(40 / 2)+10 \% \text { of the total marks } \\
(40 / 10)=20+4=\mathbf{2 4}\end{array}$} \\
\hline 3. & $\begin{array}{l}\text { I contribute to my team } \\
\text { members' learning }\end{array}$ & 18 & 5 & 6 & 1 & 4 & 3.9 \\
\hline 4. & $\begin{array}{l}\text { My contribution to the } \\
\text { team is not important }\end{array}$ & 7 & 3 & 8 & 8 & 8 & 2.8 \\
\hline 5. & $\begin{array}{l}\text { My team members } \\
\text { expect me to assist them } \\
\text { in their learning }\end{array}$ & 12 & 11 & 8 & 1 & 2 & 3.9 \\
\hline 6. & $\begin{array}{l}\text { I am accountable to my } \\
\text { team's learning }\end{array}$ & 12 & 15 & 4 & 1 & 2 & 4.0 \\
\hline 7. & $\begin{array}{l}\text { I am proud of my ability } \\
\text { to assist my team in their } \\
\text { learning }\end{array}$ & 15 & 13 & 2 & 2 & 2 & 4.1 \\
\hline \multirow[t]{2}{*}{8.} & $\begin{array}{l}\text { I need to contribute to } \\
\text { the team's learning }\end{array}$ & 10 & 8 & 8 & 5 & 3 & 3.5 \\
\hline & Total & & & & & & 30.0 \\
\hline \multicolumn{2}{|c|}{ Preference for lectures or TBL } & \multicolumn{6}{|c|}{$\begin{array}{l}\text { Total possible marks }=(16 \times 5)=\mathbf{8 0} \text {. Neutral point }=\text { midpoint } \\
(80 / 2)+10 \% \text { of the total marks }(80 / 10)=40+4=\mathbf{4 4}\end{array}$} \\
\hline 9. & $\begin{array}{l}\text { During traditional } \\
\text { lectures, I often find } \\
\text { myself thinking of } \\
\text { nonrelated things }\end{array}$ & 7 & 7 & 6 & 8 & 6 & 3.0 \\
\hline 10. & $\begin{array}{l}\text { I am easily distracted } \\
\text { during traditional lectures }\end{array}$ & 4 & 8 & 9 & 6 & 7 & 2.9 \\
\hline 11. & $\begin{array}{l}\text { I am easily distracted } \\
\text { during team-based } \\
\text { learning activities }\end{array}$ & 3 & 0 & 10 & 8 & 13 & 2.2 \\
\hline 12. & $\begin{array}{l}\text { I am more likely to fall } \\
\text { asleep during lecture } \\
\text { than during classes that } \\
\text { use team-based learning } \\
\text { activities }\end{array}$ & 2 & 5 & 7 & 8 & 12 & 2.3 \\
\hline 13. & $\begin{array}{l}\text { I get bored during } \\
\text { team-based learning } \\
\text { activities }\end{array}$ & 4 & 3 & 7 & 9 & 11 & 2.4 \\
\hline 14. & $\begin{array}{l}\text { I talk about nonrelated } \\
\text { things during team-based } \\
\text { learning activities }\end{array}$ & 1 & 1 & 7 & 10 & 15 & 1.9 \\
\hline 15. & $\begin{array}{l}\text { I easily remember what I } \\
\text { learn when working in a } \\
\text { team }\end{array}$ & 4 & 12 & 5 & 9 & 4 & 3.1 \\
\hline 16. & $\begin{array}{l}\text { I remember material } \\
\text { better when the } \\
\text { instructor lectures about } \\
\text { it }\end{array}$ & 2 & 9 & 11 & 8 & 4 & 2.9 \\
\hline 17. & $\begin{array}{l}\text { Team-based learning } \\
\text { activities help me recall } \\
\text { past information }\end{array}$ & 3 & 14 & 7 & 3 & 7 & 3.1 \\
\hline
\end{tabular}




\begin{tabular}{|c|c|c|c|c|c|c|c|}
\hline No. & Item & $\begin{array}{l}\text { Strongly } \\
\text { agree (X5) }\end{array}$ & $\begin{array}{l}\text { Agree } \\
(\mathbf{X} 4)\end{array}$ & $\begin{array}{l}\text { Neutral } \\
\text { (X3) }\end{array}$ & $\begin{array}{l}\text { Disagree } \\
(X 2)\end{array}$ & $\begin{array}{l}\text { Strongly } \\
\text { disagree } \\
\text { (X1) }\end{array}$ & $\begin{array}{l}\text { Average } \\
(\div 34)\end{array}$ \\
\hline \multicolumn{2}{|r|}{ Accountability subscale } & \multicolumn{6}{|c|}{$\begin{array}{l}\text { Total possible marks (for each student })=(8 \times 5)=40 \text {. } \\
\text { Neutral point }=\text { midpoint mark }(40 / 2)+10 \% \text { of the total marks } \\
(40 / 10)=20+\mathbf{4}=\mathbf{2 4}\end{array}$} \\
\hline 18. & $\begin{array}{l}\text { It's easier to study for } \\
\text { tests when the instructor } \\
\text { has lectured over the } \\
\text { material }\end{array}$ & 6 & 8 & 8 & 5 & 7 & 3.0 \\
\hline 19. & $\begin{array}{l}\text { I remember information } \\
\text { longer when I go over it } \\
\text { with team members } \\
\text { during the GRATS used } \\
\text { in team-based learning }\end{array}$ & 4 & 5 & 15 & 6 & 4 & 3.0 \\
\hline 20. & $\begin{array}{l}\text { I remember information } \\
\text { better after the } \\
\text { application (tAPP) } \\
\text { exercise used in } \\
\text { team-based learning }\end{array}$ & 3 & 6 & 15 & 6 & 4 & 2.9 \\
\hline 21. & $\begin{array}{l}\text { I can easily remember } \\
\text { material from lectures }\end{array}$ & 1 & 5 & 13 & 8 & 7 & 2.6 \\
\hline 22. & $\begin{array}{l}\text { After working with my } \\
\text { team members, I find it } \\
\text { difficult to remember } \\
\text { what we talked about } \\
\text { during class }\end{array}$ & 2 & 3 & 13 & 9 & 7 & 2.5 \\
\hline 23. & $\begin{array}{l}\text { I do better on exams } \\
\text { when we use } \\
\text { team-based learning to } \\
\text { cover the material }\end{array}$ & 4 & 6 & 10 & 9 & 5 & 2.9 \\
\hline 24. & $\begin{array}{l}\text { After listening to the } \\
\text { lecture, I find it difficult to } \\
\text { remember what the } \\
\text { instructor talked about } \\
\text { during class }\end{array}$ & 2 & 4 & 11 & 9 & 8 & 2.5 \\
\hline & Total & & & & & & 43.2 \\
\hline \multicolumn{2}{|c|}{ Students Satisfaction subscale } & \multicolumn{6}{|c|}{$\begin{array}{l}\text { Total possible marks }=(9 \times 5)=45 . \text { Neutral point }=\text { midpoint } \\
(45 / 2)+10 \% \text { of the total marks }(45 / 10)=22.5+4.5=\mathbf{2 7}\end{array}$} \\
\hline 25. & $\begin{array}{l}\text { I enjoy team-based } \\
\text { learning activities }\end{array}$ & 3 & 13 & 9 & 1 & 8 & 3.1 \\
\hline 26. & $\begin{array}{l}\text { I learn better in a team } \\
\text { setting }\end{array}$ & 3 & 12 & 10 & 3 & 6 & 3.1 \\
\hline 27. & $\begin{array}{l}\text { I think team-based } \\
\text { learning activities are an } \\
\text { effective approach to } \\
\text { learning }\end{array}$ & 6 & 12 & 7 & 0 & 9 & 3.2 \\
\hline 28. & $\begin{array}{l}\text { I do not like to work in } \\
\text { teams }\end{array}$ & 2 & 2 & 7 & 10 & 13 & 2.1 \\
\hline 29. & $\begin{array}{l}\text { Team-based learning } \\
\text { activities are fun }\end{array}$ & 5 & 9 & 11 & 2 & 7 & 3.1 \\
\hline 30. & $\begin{array}{l}\text { Team-based learning } \\
\text { activities are a waste of } \\
\text { time }\end{array}$ & 1 & 3 & 9 & 8 & 13 & 2.1 \\
\hline
\end{tabular}




\begin{tabular}{|c|c|c|c|c|c|c|c|}
\hline No. & Item & $\begin{array}{l}\text { Strongly } \\
\text { agree (X5) }\end{array}$ & $\begin{array}{l}\text { Agree } \\
\text { (X4) }\end{array}$ & $\begin{array}{l}\text { Neutral } \\
\text { (X3) }\end{array}$ & $\begin{array}{l}\text { Disagree } \\
(\mathbf{X} 2)\end{array}$ & $\begin{array}{l}\text { Strongly } \\
\text { disagree } \\
\text { (X1) }\end{array}$ & $\begin{array}{l}\text { Average } \\
(\div 34)\end{array}$ \\
\hline \multicolumn{2}{|r|}{ Accountability subscale } & \multicolumn{6}{|c|}{$\begin{array}{l}\text { Total possible marks (for each student })=(8 \times 5)=40 \text {. } \\
\text { Neutral point }=\text { midpoint mark }(40 / 2)+10 \% \text { of the total marks } \\
(40 / 10)=20+\mathbf{4}=\mathbf{2 4}\end{array}$} \\
\hline 31. & $\begin{array}{l}\text { I think team-based } \\
\text { learning helped me } \\
\text { improve my grade }\end{array}$ & 2 & 5 & 10 & 6 & 11 & 2.4 \\
\hline 32. & $\begin{array}{l}\text { I have a positive attitude } \\
\text { toward team-based } \\
\text { learning activities }\end{array}$ & 4 & 13 & 8 & 3 & 6 & 3.2 \\
\hline \multirow[t]{2}{*}{33.} & $\begin{array}{l}\text { I have had a good } \\
\text { experience with } \\
\text { team-based learning }\end{array}$ & 4 & 11 & 7 & 3 & 9 & 2.9 \\
\hline & Total & & & & & & 25.2 \\
\hline \multicolumn{2}{|c|}{$\begin{array}{l}\text { Average total questionnaires } \\
\text { points for all students (=total } \\
\text { average of all subscales) }\end{array}$} & \multicolumn{5}{|c|}{$\begin{array}{l}\text { Total possible marks }=(33 \times 5)=165 . \text { Neutral point } \\
=\text { midpoint }(165 / 2)+10 \% \text { of the total marks }(165 / 10) \\
=82.5+16.5=99\end{array}$} & 98.4 \\
\hline
\end{tabular}

\section{Discussion}

This study aimed to explore students' perception of TBL activities following its first implementation in our setting. Results have shown minor levels of accountability and reduced satisfaction with TBL, an inclination to didactic lectures, and overall poor rating of TBL. Livingstone et al. (2014) evaluated the application of TBL strategy in a graduate gross anatomy course for physical therapy students in three consecutive years using the TBL-SAl and reported similar findings to this study. They highlighted a slight preference to TBL in comparison to didactic lectures (mean scores of 51.355.1) which they reasoned to the struggle that students often experience when they shift from passive learning to student-centered learning strategies particularly at the beaning of such trials. In addition, they pointed a high accountability score (31.5-33.0) which they attributed to the value that students place on teams and teamwork in the TBL strategy [19]. In consonance, Mennenga (2015) explored students' perceptions of TBL upon its first implementation in a community health course in nursing. She reported high accountability score (35.5) and neutral preference for TBL over lectures (47.8). However, students were generally satisfied with the TBL approach (mean score 113.2) upon its introduction [20]. Also, Branney et al. (2018) examined nursing students' perceptions of TBL in an undergraduate pathophysiology course where one topic was experimented in the TBL format. They asserted a high accountability score (93\% of the students) which they related to the tendency of students to support their team members and contribute 
to team learning. They also reported a lower preference score than that of the other subscales which they linked to the familiarity of students with lectures [9]. Such results may explain the weak accountability and low preference scores in this study.

By contrast, some of the results of the aforementioned studies were contradicting the findings of this study, which might shed light on the possible role of the context and the learning environment. Moreover, Livingstone et al. (2014) argued that "millennial" students have learning styles which may match the TBL methodology, which is not supported by this study. Nevertheless, Moor-Davis et al. (2015) argued that reforming a course into TBL design in clinical rotations is daunting and necessitates considerable effort from teachers, and possibly all parties in the educational climate [19]. Besides, Junca et al. (2017) argued that short duration of the course, like the case in this study, might not permit adequate exposure to the TBL method and may likely diminish students' perception of its usefulness to their career and learning [14].

It is well-known that some barriers converge on TBL upon its initial experimentation and may critically determine its acceptability and outcomes. These involve a complex interplay of factors related to students, teachers, the prevailing instructional methods, and the institution's educational climate [17], and will be discussed below in more details.

\subsection{Barriers to TBL implementation}

\subsubsection{Unfamiliarity with TBL}

Sharma et al. (2017), who reported findings similar to this study, attributed their results to the short duration and unfamiliarity of instructors with TBL usage [21]. In consonance, Livingstone et al. (2014) reported a slight preference to TBL over didactic lectures that they reasoned to the unfamiliarity of students in their series with student-centered learning strategies as mentioned earlier [19]. Several studies have pointed out the difficulty that students and teachers often face to engage with TBL approaches when they are not accustomed to this active pedagogical method [2, 8, 9, 14, 21-23].

\subsubsection{Changing learners and teachers' roles}

In a TBL medium, students are expected to comprehend pre-reading assignments and participate effectively with their teammates to discuss and solve in-class exercises in order to achieve the envisaged goals of their learning. Therefore, students' role would shift to that of an active learner rather than a passive listener, and the expectations 
would drift away from just receiving information to sound application of knowledge in real-world problems $[10,24]$. This significant change in the students' role added to the workload of pre-class reading and unfamiliarity with TBL would risk bring some of them out of their "comfort zone" and hamper their acceptability and engagement with TBL activities. This is particularly eminent, where passive reception of information in traditional classes is the norm in their learning atmosphere [3, 12, 24]. It was explicated that students who tend to attain "non-participatory" anonymity in didactic lectures can no longer maintain that in an active TBL environment where they found themselves exposed to their peers and teachers and may, therefore, resent such promising learning methods [9]. In fact, one of the desired skills of facilitation in TBL sessions is the ability to spot and engage those students who tend to sit in far corners to hide themselves [25]. In addition, some students' traits may play a role as it has been noted that students with introverted personalities and passive attitude toward learning may face trouble in engaging with TBL activities [26].

Teachers, who play a crucial role in the process, may also suffer alike where they find themselves unacquainted to the knowledge and skills required to manage TBL classes and lack the necessary training to facilitate its activities [8,24]. Teachers should accept the responsibility to espouse behavioral and attitudinal changes that resonate with their new role as facilitators rather than knowledge transmitters and to prepare exercises that engage students and nourish discussion, which, although difficult can be learned [3, 25]. Fujikura et al. (2013) reported similar results to this study from a medical school in Japan, where a new curricular design similar to what is applied in this study was experimented [27]. They highlighted low preference to TBL among the fourth-year students compared to other forms of small-group learning, which they related to the quality of the preparation material. Moreover, they highlighted the dissatisfaction that teachers exhibited with the TBL approach due to the burden of selecting and preparing useful teaching guides. Such difficulties that TBL poses to students and teachers are perceived as the inaugural cost that they need to endure before they embark on the method and embrace its benefits [24].

\subsection{Improving perceptions toward TBL}

\subsubsection{Early and sustained practice}

Some researchers have demonstrated improvement in TBL perceptions after some period of practice. Mennenga (2015) studied reform of a community health course in 
nurse education into TBL format at one time and two years later. She pointed to an initial period of students' frustration with the TBL approach and how they resented its implementation as the prime instructional method. She quoted some students verbalization of this resentment like; "This (TBL) isn't the way we learn"(p. 77). However, two years later, she reported substantial improvement in students' perceptions and attitude toward TBL and increased acceptance. She concluded that students need some period of adjustment to cope with their demands and new roles in TBL exercises [20]. Likewise, Figurero et al. (2015) evaluated application of TBL in a women health clerkship where she reported that the majority of students were initially unaware of the TBL and that more than half of them doubted the benefit of the method to their learning. However, after some period of practice, $60 \%$ of the students preferred TBL over lectures and all of them perceived a positive impact on their learning. Even later, and during their internship, 55\% of the students felt that TBL has improved their practical skills, for example, decision-making [28]. Also, Livingstone et al. (2014) examined the use of TBL for graduate physical therapy students in three consecutive years as mentioned earlier. They displayed an increase in the students' scores of all subscales of the TBL-SAI, particularly the satisfaction component (mean scores of 32.7-38) and confirmed an overall positive perception of TBL in the third trail in comparison to the first two cohorts.

Some reports have revealed that early exposure to TBL, particularly when used as the major instructional method, is imperative to its successful application [7, 16, 22]. Other studies recommended the early introduction of flipped classrooms in the curriculum and in association with TBL to shift the pendulum movement toward active learning strategies and accustom students for their use early in the course of their studies [21]. This is supported by Rajalingam et al. (2018) at a medical college in Singapore who showed positive results of TBL where it was used as the prime teaching strategy [29]. It was argued that students tend to prefer passive rather than active learning methods when both strategies are used simultaneously, like the case in this study [3, 26)]. MooreDavis et al. (2015) suggested that designing a course in the TBL format requires teachers to work hard to revamp their educational material into one that suits the new learning model. However, once created, they could carry it over and consequently experience less pressure in terms of time and effort. They also added that students might initially feel frustrated with the TBL activities; however, this would likely change over some period of practice $[16,19,20,23,30]$. Fortunately, it was shown that students would still perceive TBL activities positively when they appreciate the vital implications that TBL conveys to their future career [9, 29, 31]. Branney and Priego-Hernández (2018) explained the positive perception of students to TBL in their setting to the relevance of TBL activities 
that the latter have seen to the nature of work in the clinical environment [9]. Having mentioned the importance of early incorporation of TBL activities in the curriculum, it should be emphasized that careful balance and coordination of TBL activates within and among courses beside consideration of the examination schedules is essential to avoid overwhelming the students with daunting workload and hence decrease the outcomes $[16,27]$.

In contrast, Zachry et al. (2017) highlighted that students in their series preferred traditional lectures to TBL and concluded that the former "still has a place in the college classroom" [21; p. 7]. Of course, the provision of some instruction the end of TBL sessions to clarify concepts and resolve remaining uncertainties would allow for proper closure and could be as vital in TBL as in formal lectures [5, 7, 9, 12, 14, 22, 25]. MoorDavis et al. (2015) investigated revision of a didactic midwifery masters level course into a TBL design. They reported improvement in students' evaluation of the TBL method when teachers added recorded lectures. They argued that modification of the TBL method might be necessary to address the needs of the students. Likewise, Branney Priego-Hernández (2018) noted a low preference to TBL sessions among the students in their study. They explained that TBL might not be applicable in every setting, and that alignment of the process to the context is important [30]. Thus, it appears that the judicious use of mixed instructional methods customized to the nature of the subject, the educational climate, and the level of familiarity and expertise of faculty and students is a practical strategy $[24,27]$.

\subsubsection{Faculty development}

The importance of faculty development programs to train teachers to accomplish their roles as facilitators and to create functional application exercises that engage students and promote learning and teamwork cannot be overemphasized [1, 16, 22]. The desired teachers' skills also encompass thoughtful formation of students' groups, communication of goals, selection of appropriate pre-reading material, and careful planning for the sessions, including time management, which, although challenging at the beginning can be mastered [3, 25]. TBL hinges on appropriate students' orientation to the objectives and methodology of the process and its numerous advantages to their career and course coordinators should address these concerns assiduously. Of course, such efforts should be complemented with educational values and institutional norms that endear the deliberate use of active learning strategies at all stages of study and encourage students and teachers to buy-in the process $[3,8,16]$. 
Finally, consideration of the aforementioned strategies would enable all parties in the educational process to exploit the benefits of TBL and create a learning environment conducive to active learning $[2,21,32,33]$. It has been emphasized that students' perception of TBL depends after all on the interplay of all the factors mentioned earlier and their influence on each other rather than the mere execution of TBL steps $[3,16,26]$. For instance, Thompson et al. (2007) reported on the application of TBL in 10 medical schools at one time and then two years later. They highlighted faculty experience with the method, the confidence that they acquire with repeated practice, and professional development as crucial ingredients of the TBL process. They also substantiated the vital roles of the administrative support and the learning environment in defining TBL outcomes [16]. The results of some studies were encouraging and demonstrated a positive transformation in students' perceptions and attitude toward TBL after a preliminary period of poor results $[9,16,29]$. However, some other studies reported mixed results $[5,29,34]$. Therefore, longitudinal studies are required to explore in-depth role and interaction of the factors ambient to the TBL strategy in our environment.

This study is limited by the small number of participants and being conducted in one course and a single class in the college. As such, the results cannot be generalized to other settings. It is also limited by the small number of TBL activities conducted in the course (eight sessions) to the other teaching methods. However, the findings of this study would still provide an insight into the factors that revolve around TBL implementation in our environment and set the stage to improve its future practice. Further studies would be required to explore the perils and promises of the TBL approach and inform the best way of its implementation in our setting.

\section{Conclusion}

TBL is an active, student-centered approach to learning that is widely used nowadays in medical education programs. The method has been introduced recently in our setting to enhance students learning and promote their professional growth. Preliminary results showed a minor level of accountability, weak preference and satisfaction, and an overall poor TBL rating. These results can be attributed to the unfamiliarity of students and teachers with TBL approaches and the difficulty that they may experience to attain their new roles to cope with it. Perseverance and strong commitment to sustain TBL approaches are crucial at the beginning of such projects and would eventually set the stage for better outcomes. With repeated practice and adequate institutional support, 
TBL knowledge and skills would fleet into the college's atmosphere, and gradually all parties would reap its numerous advantages to practice and learning.

\section{Acknowledgments}

The author would like to express his gratitude to the copyright holder of the TBL-SAl who granted permission to use it in this study. He is also grateful to the fourth-year students for their participation in this research.

\section{Ethical Considerations}

This study was approved by the institutional review board of the College of Medicine (PSAU/COM/RC/IRB/P/78 and supported by the Deanship of Scientific Research at Prince Sattam bin Abdul-Aziz University, Al-Kharj, Saudi Arabia. The copyright holder granted permission to use the TBL-SAl in this study. Questionnaires were administered anonymously by the department of medical education three months after the conclusion of the course.

\section{Competing Interests}

The author reports no conflict of interest.

\section{Availability of Data and Material}

All relevant data and methodological details pertaining to this study are available to any interested researchers upon reasonable request to corresponding author.

\section{Funding}

None.

\section{References}

[1] Branson, S., Boss, L., and Fowler D. (2016). Team-based learning: application in undergraduate baccalaureate nursing education. Journal of Nursing Education and Practice, vol. 6, no. 4, pp. 59-64. 
[2] Balan, P., Clark, M., and Restall, G. (2015). Preparing students for flipped or teambased learning methods. Education + Training, vol. 57, no. 6, pp. 639-657.

[3] Kibble, J., Bellew, C., Asmar, A., et al. (2016). Team-based learning in large enrollment classes. Advances in Physiology Education, vol. 40, no. 4, pp. 435-442.

[4] Parmelee, D., Michaelsen, L., Cook, S., et al. (2012). Team-based learning: a practical guide: AMEE Guide No. 65. Medical Teacher, vol. 34, no. 5, pp. e275-e287.

[5] Smeby, S., Lillebo, B., Slørdahl, T., et al. (2020). Express team-based learning (eTBL): a time-efficient TBL approach in neuroradiology. Academic Radiology, vol. 27, no. 2, pp. 284-290.

[6] Schaik, S. and O'Brien, B. (2015). More chickens, fewer eggs? On team-based learning, team performance and teamwork skills. Medical Education, vol. 49, no. 4, pp. 344-354.

[7] Compton, S., Kamei, R., and Cook, S. (2016). The history and future of team-based learning. Proceedings of Singapore Healthcare, vol. 25, no. 1, pp. 3-4.

[8] Haidet, P., Kubitz, K., and McCormack, W. (2014). Analysis of the team-based learning literature: TBL comes of age. Journal on Excellence in College Teaching, vol. 25, no. 3-4, pp. 303-333.

[9] Branney, J. and Priego-Hernández, J. (2018). A mixed methods evaluation of teambased learning for applied pathophysiology in undergraduate nursing education. Nurse Education Today, vol. 61, pp. 127-133.

[10] Simonson, S. (2014). Making Students do the thinking: team-based learning in a laboratory course. Advances in Physiology Education, vol. 38, no. 1, pp. 49-55.

[11] Zgheib, N., Simman, J., and Sabra, R. (2010). Using team-based learning to teach pharmacology to second year medical students improves student performance. Medical Education, vol. 32, no. 2, pp. 130-135.

[12] Mousavi, M., Amini, M., Delavar, S., et al. (2019). Using team-based learning to teach evidence-based medicine to first-year residents. Acta Facultatis Medicae Naissensis, vol. 36, no. 1, pp. 60-68.

[13] Tan, A., Chaudhary, Z., Hawa, R., et al. (2016). Healing conversations in medicine: making every encounter therapeutic. Medical Education, vol. 50, no. 11, pp. 11481148.

[14] Junca, G., Belli, D., and Bajwa, N. (2017). Team-based learning to contextualise evidence-based practice for residents. Medical Education, vol. 51, no. 5, pp. 542543. 
[15] Rider, E., Brasher, V., and Costanza, M. (2008). Using interprofessional team-based learning to develop health care policy. Medical Education, vol. 42, no. 5, pp. 519520.

[16] Thompson, B., Schneider, V., Haidet, P., et al. (2007). Team-based learning at ten medical schools: two years later. Medical Education, vol. 41, no. 3, pp. 250-257.

[17] Bergquist, E., Anderson, J., Johnson, J., et al. (2017). Team based learning activities improve application of the nutrition care process in a dietetic internship. Journal of the Academy of Nutrition and Dietetics, vol. 117, no. 9, p. A71.

[18] Mennenga, H. (2012). Development and psychometric testing of the team-based learning student assessment instrument. Nurse Educator, vol. 37, no. 4, pp. 168-172.

[19] Livingston, B., Lundy, M., and Harrington, S. (2014). Physical therapy students' perceptions of team-based learning in gross anatomy using the Team-Based Learning Student Assessment Instrument. Journal of Educational Evaluation for Health Professions, vol. 11, p. 1.

[20] Mennenga, H. (2015). Time to adjust; team-based learning 2 years later. Nurse Educator, vol. 40, no. 2, pp. 75-78.

[21] Sharma, A., Janke, K., Larson, A., et al. (2017). Understanding the early effects of teambased learning on student accountability and engagement using a three session TBL pilot. Currents in Pharmacy Teaching and Learning, vol. 9, no. 5, pp. 802-807.

[22] Zachry, A., Nash, B., and Nolen, A. (2017). Traditional lectures and team-based learning in an occupational therapy program: a survey of student perception. The Open Journal of Occupational Therapy, vol. 5, no. 2, article 6.

[23] Parmele, D., DeStephen, D., and Borges, N. (2009). Medical students' attitudes about team-based learning in a preclinical curriculum. Medical Education Online, vol. 14, p. 1.

[24] Huggins, C. and Stamatel, J. (2015). An exploratory study comparing the effectiveness of lecturing versus team-based learning. Teaching Sociology, vol. 43, no. 3, pp. 227-235.

[25] Gullo, C., Ha, T., and Cook, S. (2015). Twelve tips for facilitating team-based learning. Medical Teacher, vol. 37, no. 9, pp. 819-824.

[26] Cunha, M., Amendola, F., Samperiz, M., et al. (2018). Evaluation of student perception of the team-based learning method (APA-TBL): instrument construction and validation. Nurse Education in Practice, vol. 33, pp. 141-147.

[27] Fujikura, T., Takeshita, T., Homma, H., et al. (2013). Team-based learning using an audience response system: a possible new strategy for interactive medical education. Journal of Nippon Medical School, vol. 80, no. 1, pp. 63-69. 
[28] Figuero-Filho, E., Reis, F., Goncalves, L., et al. (2015). Team-based learning during clerkships: a cohort study. Medical Teacher, vol. 49, no. 11, pp. 1156-1156.

[29] Rajalingam, P., Rattans, J., Zary, N., et al. (2018). Low-beer N. Implementation of teambased learning on a large scale: three factors to keep in mind. Medical Teacher, vol. 40, no. 6 , pp. 582-588.

[30] Moore-Davis, T., Schorn, M., Collins, M., et al. (2015). Team-based learning for midwifery education. Journal of Midwifery \& Women's Health, vol. 60, no. 3, pp. 291-297.

[31] Fatmi, M., Hartling, L., Hillier, T., et al. (2013). The effectiveness of team-based learning on learning outcomes in health professions education: BEME Guide No. 30. Medical Teacher, vol. 35, no. 12, pp. e1608-e1624.

[32] Rotgan, J., Rajalingam, P., Ferenczi, M., et al. (2018). A students' model of team-based learning. Health Professions Education, vol. 5, no. 4, pp. 294-302.

[33] Thompson, B., Haidet, P., Borges, N., et al. (2015). Team cohesiveness, team size and team performance in team-based learning teams. Medical Education, vol. 49, no. 4, pp. 379-385.

[34] Parmele, D., DeStephen, D., and Borges, N. (2009). Medical students' attitudes about team-based learning in a preclinical curriculum. Medical Education Online, vol. 14, no. 1, p. 4503. 


\section{Appendix}

-The TBL-SAl; Arabic translations were added beside the original questions to address the language concerns and increase the credibility of the results.

\section{Department of Surgery}

\section{Surgery-1 Course, 2019-2020}

\section{Team-Based learning evaluation Study}

This instrument asks you about your experience with team-based learning. There are no right or wrong answers. Please be honest and report your reaction to each question by circling the number for the response that best describes your answer.

$$
\text { عدم كتابة إسمك على الإستبانة صمثت لتقيم إنطباعك عن عملية التعلم فى فريق. الرجاء الإجابة على الاسئلة بكل دقة وأمانة. الرجاء }
$$

1. Accountability Scale (مقياس المسؤلية تجاه الفريق):

This subscale assesses student preparation for class and contribution to the team:

$$
\text { مقياس مدى تحضير الطالب للنشاط و مساهمته فى الفريق }
$$

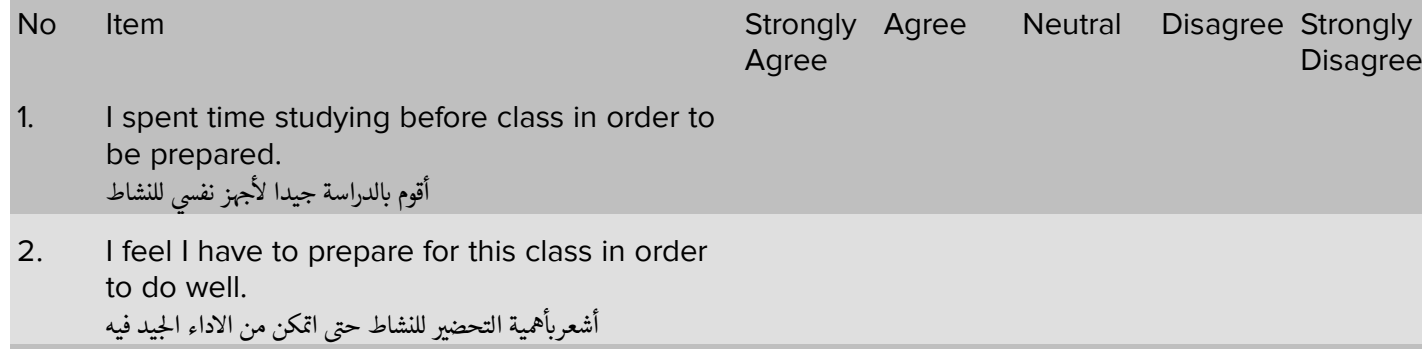

1. I spent time studying before class in order to be prepared. أقوم بالدراسة جيدا لأجهز نفسي للنشاط

2. I feel I have to prepare for this class in order to do well. أشعربأهمية التحضير للنشاط حتى اتكن من الاداء الجيد فيه

3. I contribute to my team members' learning. أسام: في مساعدة زملائى في الفريق على التعلم

4. My contribution to the team is not important. لا لا أساهم جيدا في نثاط الفريق

5. My team members expect me to assist them in their learning. زملائي فى الفريق يتوقعون مني مساعدتهم على التعلم

6. I am accountable to my team's learning. أشعر بالمسؤولية تجاه تعلم فريقى

7. I am proud of my ability to assist my team in their learning. انا فخور بمقدرتي على مساعدة رملائي علي التعلم.

8. I need to contribute to the team's learning. أشعر بالحوجة للمساهمة في عملية تعلم الفريق

2. Preference for lecture or team-based learning: (أفضلية المحاضرات أم علية التعلم في فريق):

This subscale assesses student ability to recall material and student attention level in lecture and team-based learning: 


\section{مقياس مقدرة الطالب علي إستحضار المعلومات و مدى الاتتباه مقارنة بين المحاضرات و عملية التعلم فى فريق}

No Item

9. During traditional lectures, I often find myself thinking of non-related things.

خلال المحاضرات التقليدية , أجد نفسي أفكر فى أشياء ليست لما صلة

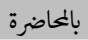

10. I am easily distracted during traditional lectures.

أسهو بكل سهولة اثناء المحاضرات التقليدية .

11. I am easily distracted during team-based learning activities.

أسهو بكل سهولة خلال عملية التعلم في فريق.

12. I am more likely to fall asleep during lecture than during classes that use team-based learning activities.

إحتال إن أنام اكبر خلال المحاضرات منه اثناء عملية التعلم فى فريق.

13. I get bored during team-based learning activities.

أشعر بالضحر أثناء نشاطات التعلم فى فريق.

14. I talk about non-related things during team-based learning activities.

أتكلم في أشياء خارجة عن الموضوع أثناء نشاطات التعلم فى فريق.

15. I easily remember what I learn when working in a team.

$$
\text { أستطيع أن أستحضر المعلومات بسهولة عندما أتعلم فى فريق. }
$$

16. I remember material better when the instructor lectures about it.

أستطيع أن أستحضر المعلومات بصورة أكبر عندما أتلقاها عن طريق ألمأق

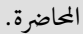

17. Team-based learning activities help me recall past information.

تساعدني نشاطات التعلم في فريق علي إستحضار المعلومات السابقة.

18. It's easier to study for tests when the instructor has lectured over the material.

يسهل التحضير للإختبارات عندما أثلىى المعلومات عن طريق المحاضرة.

19. I remember information longer when I go over it with team members during the GRATS used in team-based learning.

أستحضر المعلومات لفترة أطول عندما أتلقاها من خلال المناقشة الجماعية في الفريق.

20. I remember information better after the application (tAPP) exercise used in team-based learning.

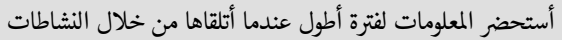
التطبيقية و الجماعية في الفريق.

21. I can easily remember material form lecture. أستطيع إستحضار المعلومات من المحاضرات بكل سهولة.

22. After working with my team members, I find it difficult to remember what we talked about during class.

أشعر بصعوبة فى إستحضار المعلومات التي ناقشتها مع زملائي خلال عملنا كفريق. - مخلان.

Agree Disagree




\begin{tabular}{|c|c|c|c|c|c|c|}
\hline No & Item & $\begin{array}{l}\text { Strongly } \\
\text { Agree }\end{array}$ & Agree & Neutral & Disagree & $\begin{array}{l}\text { Strongly } \\
\text { Disagree }\end{array}$ \\
\hline 23. & $\begin{array}{l}\text { I do better on exams when we use } \\
\text { team-based learning to cover the material. } \\
\text { أودي بشكل أفضل في الإختبارات عندما أتعلم من خلال فريق لتغطية المقرر. }\end{array}$ & & & & & \\
\hline 24. & $\begin{array}{l}\text { After listening to the lecture, I find it difficult to } \\
\text { remember what the instructor talked about } \\
\text { during class. } \\
\text { أجد صعوبة في إستحضار ما تم إلقاؤه من معلومات أثناء المحاضرات. }\end{array}$ & & & & & \\
\hline
\end{tabular}

3. Student satisfaction subscale (مدى رضى الطالب عن علية التعلم فى فريق):

This subscale assesses student satisfaction with team-based learning:

$$
\text { قياس مدى رضى الطالب عن عملية التعلم فى فريق: }
$$

$\begin{array}{lll}\text { No Item } & \begin{array}{l}\text { Strongly } \\ \text { Agree }\end{array} & \text { Agree Neutral Disagree Strongly } \\ \text { Disagree }\end{array}$

25. I enjoy team-based learning activities.

$$
\text { أستمتع بنشاطات التعلم فى فريق. }
$$

26. I learn better in a team setting. أتعلم بصورة أفضل من خلال العمل ضمن فريق

27. I think team-based learning activities are an effective approach to learning. أعتقد أن عملية التعلم فى فريق هي طريقة فعالة للتعلم.

28. I do not like to work in teams. لا أحب أن أعل ضمن فريق.

29. Team-based learning activities are fun. نشاطات التعلم في فريق ممتعة.

30. Team-based learning activities are a waste of time.

نثاطات التعلم في فريق مضيعة للوقت.

31. I think team-based learning helped me improve my grade.

أعتقد أن عملية التعلم فى فريق ساعدتي على تحسين درجاتي.

32. I have a positive attitude towards team-based learning activities.

لدي إحساس جيد و ميول تجاه علية التعلم فى فريق.

33. I have had a good experience with team-based learning.

لدي تجربة جيدة مع علية التعلم فى فريق.

4. Please add any comments you may have about your experience with teambased learning: 
Copy right of Mennenga HA (2012). Permission was granted by the copyright holder to administer this instrument to evaluate TBL implementation in surgery-1 course 20192020. 